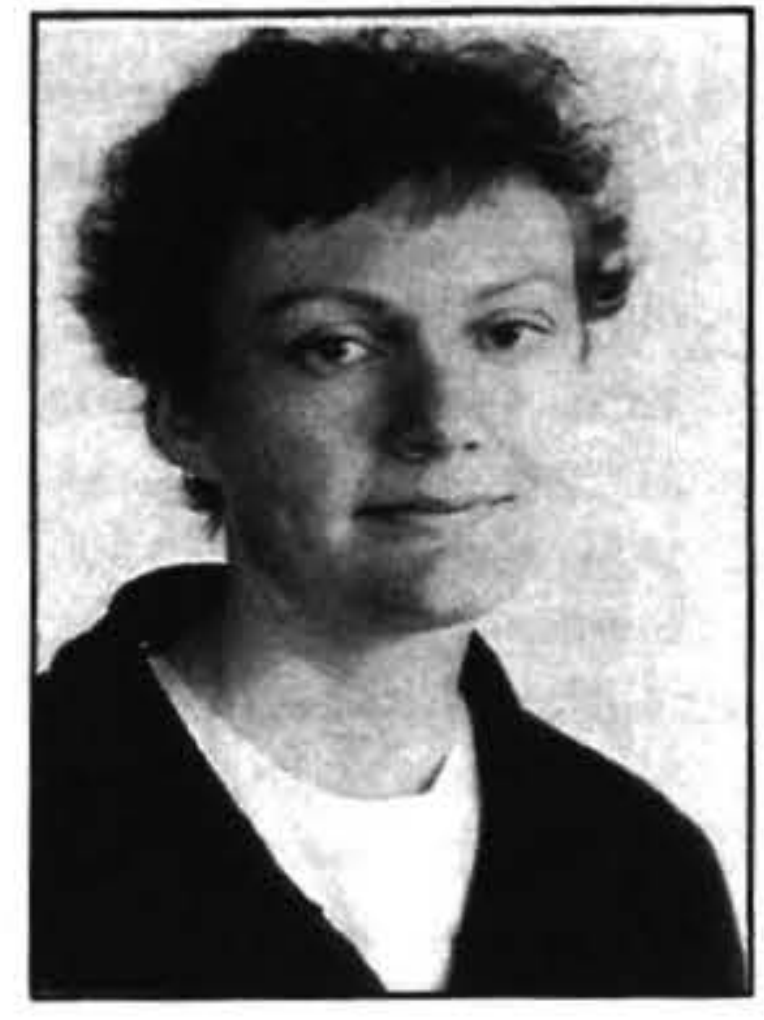

\title{
THE DISTRIBUTION OF EARNINGS IN NEW ZEALAND 1984-1995
}

\author{
Sylvia Dixon
}

Labour Market Policy Group
Department of Labour

\begin{abstract}
Changes in the distribution of individual earnings between 1984 and 1995 are examined using data from the Household Economic Survey. Several dimensions of changes in the earnings structure are considered, including measures of aggregate earnings inequality, the gender earnings gap and shifts in relative earnings by level of educational attainment. Changes in the variance of earnings are decomposed to identify more clearly the source of the tendencies towards and against greater inequality. Evidence is found of a rise in hourly earnings inequality among males over the decade. However, the effects of this trend on the total earnings distribution were offset by a rise in the female share of employment and a narrowing of the gap between male and female average hourly earnings.
\end{abstract}

Between 1984 and 1995, New Zealand experienced a prolonged recession featuring a substantial contraction of employment, followed by a period of economic recovery characterised by strong employment growth. Wide ranging economic and social policy reforms were also implemented over the decade, including measures to deregulate financial and product markets, reduce trade barriers, and liberalise the laws governing employment and industrial relations. In the light of these changes, concerns have been expressed that there may be growing inequality in the distribution of labour income among individuals.

This paper reports results from a Department of Labour research programme which is investigating long-run changes in the earnings structure, using data from the Household Economic Survey. It updates and extends results presented in Dixon (1996). The paper begins with a brief discussion of international research relating to this topic. This is followed by a description of the data used in the research. The remainder of the paper presents information on the main dimensions of change in the earnings distribution.

\section{Previous research}

The distribution of wage and salary earnings widened in a number of OECD countries during the 1980s. In a 1993 review, the OECD found evidence of rising earnings inequality in twelve of the seventeen countries considered, including the United Kingdom, the United States, Australia, Canada, Sweden and Japan. These increases were generally small, except in the United Kingdom and the United States, which experienced quite large changes in earnings dispersion over a relatively short period of time (OECD, 1993, p.157). Gregg and Machin (1994) and Katzet al (1993) draw similar conclusions from cross-national comparisons.
In a more recent review of developments the OECD presents evidence indicating that there was not a generalised increase in earnings inequality in the first half of the 1990s. Only the United States and the United Kingdom continued to experience a rapid rise in inequality. The relative earnings of higher paid workers continued to drift upwards in a few other countries, but those trends were neither very strong nor consistent for both males and females (OECD, 1996: 63).

Increases in the relative earnings of more highly educated workers, and reductions in the relative earnings of those with little education, were a key feature of the growth of earnings inequality in several OECD countries in the 1980s. In the United States, for example, the ratio of the median earnings of college- educated males to those of males with high school education only rose from 1.37 in 1979 to 1.51 in 1987 (OECD, 1993:171). Smaller increases in the earnings premium for tertiary educated labour were experienced in Germany, Sweden and the United Kingdom during the 1980s (Nickell and Bell, 1996:303 and OECD, 1993:171). Increases in earnings differentials related to age or years of experience in the labour force were also recorded in a number of countries, including Canada, Sweden, the United States, and the United Kingdom (Katz and Murphy, 1992; OECD, 1993:160). Countering these tendencies towards greater inequality, many OECD countries experienced reductions in the gaps between average male and average female earnings (Gunderson, 1989:47; Katz et al, 1993).

There is a large body of research on the causes of the growth in earnings inequality recorded in the US and elsewhere (see Levy and Murnane, 1992, for a review). The potential explanations explored in this literature include: shifts in the supply of specific skills or types of labour (Katz and Murphy, 1992; Murphy and Welch, 1992); increasing returns to 
unmeasured skills, such as IQ or problem-solving ability (Blackburn and Neumark, 1993), skill-biased technological change (Katz and Murphy, 1992), the decline of union coverage (Freeman, 1993), and the effects of international trade deregulation on the demand for less skilled labour (Murphy and Welch, 1991).

Studies of the distribution of total incomes across New Zealand households have shown that there was an increase in household income inequality between 1982 and 1993 (New Zealand Planning Council, 1988 and 1990; Mowbray, 1993; and Mowbray and Dayal, 1994). However, little empirical evidence has been available until recently on the distribution of individual earnings from wage and salaried employment.

\section{The data}

The Household Economic Survey (HES) is a survey of people living in private households. Income data, including details of any wages or salaries earning during the preceding 12 months, are collected from each adult in the survey. This paper utilises information on individuals' total gross (pretax) hourly and weekly earnings in their current jobs (those held at the time of their interview). Overtime payments, allowances, bonuses and commissions are included in the earnings estimates. The hourly figures were obtained by dividing the estimates of each individuals' weekly earnings by their usual weekly hours. Full details of the data and methods of analysis, and information on the demographic characteristics of the samples of earners, are given in Dixon (1996).

Each year, the HES collects data form around 3,000 people with current wage and salary jobs. Because these annual samples are quite small, the estimates obtained are subject to relatively large sampling errors and tend to be quite volatile from year to year. To avoid drawing misleading conclusions, it is important to focus on the trends apparent when several years are considered together, and not attach too much significance to particular estimates. Several population sub-groups considered in this study have fewer than 500 observations in any given year: older workers (aged 55 and over); Mäori; members of other minority ethnic groups; and workers with university qualifications. Particular care should be taken in interpreting the results relating to these groups.

\section{Aggregate changes in earnings inequality}

It is useful to begin an examination of the earnings structure with some background information on movements in average wage levels. Taking the official nominal wage statistics and adjusting for inflation, the general picture obtained is of rising real earnings in the 1980 s, followed by stagnation in the first half of the 1990s. The total rise in the average level of real wages over the decade was modest. Estimates of its exact size vary, depending on which measures of nominal earnings and which price deflators are used. ${ }^{1}$

Three alternative measures of movements in real total hourly earnings over the last eleven years are graphed in Figure 1. The HES measure of total hourly earnings in all jobs, deflated by the official CPI, shows real hourly wages falling in the mid 1980s, picking up in the late 1980s, falling in the early 1990 s and finally increasing a little between 1994 and 1995. However, it is conceptually more consisted to use a GST-adjusted CPI to deflate gross earnings, because the introduction of GST in the 1980s was accompanied by a simultaneous reduction in direct income taxes, intended to offset the impact of higher indirect taxes on the real value of

Figure 1: Changes in average hourly earnings in constant dollars, 1984-96

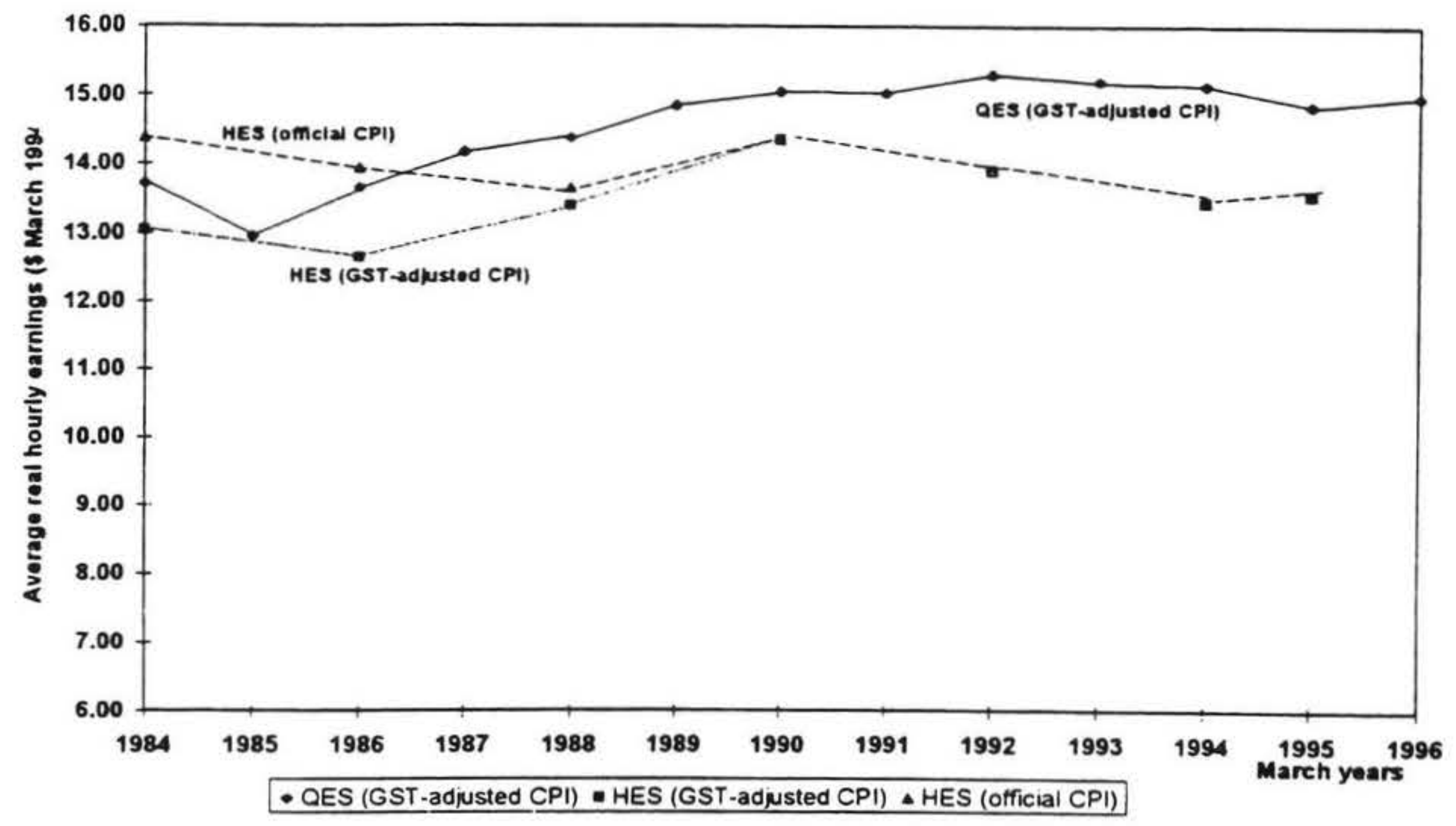


after tax earnings. ${ }^{2}$ The HES series deflated by the CPI excluding GST effects ${ }^{3}$ shows stronger growth during the 1980 s. According to this measure, real total hourly earnings increased by a total of 3.9 percent over the 1984 to 1995 period. Growth in real earnings during the 1980 s was offset by a decline in the early 1990 s.

An alternative measure of real earnings, QES average total hourly earnings divided by the CPI (also net of GST effects), also shows rising real wages during the 1980 s and a contraction in the real value of wages during the early 1990s although it shows a smaller decline occurring over a shorter period. According to this measure, the real value of total hourly earnings increased by 8.2 percent over the eleven years from March 1984 to March $1995 .{ }^{4}$ Both series indicate that over the decade as a whole, the net improvement in the real value of earnings was relatively small.

Further information from the HES on trends in real earnings between 1984 and 1995 is summarised in Table 1. The figures presented here and elsewhere in this paper have been converted to constant March 1994 dollars using the GSTadjusted CPI calculated by the RBNZ. ${ }^{5}$ The average weekly earnings of all employees, and the average weekly earnings of full-time employees, both increased by a little less than 10 percent. The growth in average weekly earnings exceeded the growth in average hourly earnings because of a 5.8 percent increase in the average number of hours worked, from 36.6 per week to 38.7 hours per week.

Both male and female wage and salary earners experienced rising real hourly earnings between 1986 and 1990 and falling real hourly earnings in the early 1990s. The increases in the late 1980 s were larger for females than those for males, however, while the reductions in the early 1990s were smaller. Over the period as a whole, male hourly earnings fell slightly, while female hourly earnings increased by around 10 percent.

Table 2 reports the results obtained when several different summary measures of earnings inequality were calculated for the total population of employees and for subgroups. It is clear that there were significant increases in the dispersion of weekly earnings, both across the total population of employees and across full-time employees. All measures show greater dispersion in 1995 than in 1984. For example, the coefficient of variation in the distribution of weekly earnings across all employees rose from 58.9 to 69.3 . The ratio of the ninetieth percentile in the distribution to the tenth percentile rose from 6.15 in 1984 to 6.62 in 1995 . Both the upper and lower ends of the distribution show signs of movement away from the median (as indicated by the $90 / 50$ and $10 / 50$ percentile ratios). The inequality of weekly earnings across full-time employees also increased, indicating that the rise in the dispersion of weekly earnings was not simply the result of increases in the share of part-time employment. That increase occurred between 1986 and 1990 , and did not continue into the 1990s.

The summary measures of the dispersion of total hourly earnings across all employees do not offer such a clear cut picture. They suggest that the amount of inequality in the hourly earnings distribution was stable between 1984 and 1988, increasing between 1988 and 1990, and then stable after 1990. While the coefficient of variation and the standard deviation of log earnings were slightly higher at the

Table 1. Trends in average real earnings

\begin{tabular}{|c|c|c|c|c|c|c|}
\hline & \multicolumn{3}{|c|}{$(\$$ March 1994) } & \multirow{2}{*}{$\begin{array}{l}\% \text { chge } \\
1984-90\end{array}$} & \multirow{2}{*}{$\begin{array}{l}\% \text { chge } \\
1990-95\end{array}$} & \multirow{2}{*}{$\begin{array}{l}\% \text { chge } \\
1984-95\end{array}$} \\
\hline & 1984 & 1990 & 1995 & & & \\
\hline \multicolumn{7}{|c|}{ Weekly earnings, all employees } \\
\hline Mean & 484.81 & 541.35 & 531.85 & 11.7 & -1.8 & 9.7 \\
\hline Median & 456.79 & 495.79 & 486.89 & 8.5 & -1.8 & 6.6 \\
\hline Mean of $\log$ values & 382.34 & 426.76 & 412.39 & 11.6 & -3.4 & 7.9 \\
\hline \multicolumn{7}{|c|}{ Weekly earnings, full-time employees } \\
\hline Mean & 564.48 & 628.87 & 618.84 & 11.4 & -1.6 & 9.6 \\
\hline Median & 515.2 & 564.78 & 545.9 & 9.6 & -3.3 & 6 \\
\hline Mean of $\log$ values & 514.91 & 561.98 & 547.22 & 9.1 & -2.6 & 6.3 \\
\hline \multicolumn{7}{|c|}{ Hourly earnings, all employees } \\
\hline Mean & 13.04 & 14.35 & 13.55 & 10.1 & -5.6 & 3.9 \\
\hline Median & 11.81 & 12.72 & 12.12 & 7.7 & -4.7 & 2.7 \\
\hline Mean of log values & 11.8 & 12.76 & 12.06 & 8.1 & -5.5 & 2.2 \\
\hline \multicolumn{7}{|l|}{ Weekly hours } \\
\hline Mean & 36.61 & 37.22 & 38.74 & 1.7 & 4.1 & 5.8 \\
\hline Mean of $\log$ values & 40 & 40 & 40 & 0 & 0 & 0 \\
\hline \multicolumn{7}{|l|}{ Male hourly earnings } \\
\hline Mean & 14.35 & 15.65 & 14.4 & 9 & -8 & 0.3 \\
\hline Median & 13.04 & 13.95 & 12.58 & 7 & -9.8 & -3.5 \\
\hline Mean of log values & 12.98 & 13.87 & 12.68 & 6.8 & -8.6 & -2.4 \\
\hline \multicolumn{7}{|c|}{ Female hourly earnings } \\
\hline Mean & 11.26 & 12.79 & 12.82 & 13.6 & 0.2 & 13.9 \\
\hline Median & 10.32 & 11.55 & 11.23 & 11.9 & -2.8 & 8.8 \\
\hline Mean of log values & 10.37 & 11.54 & 11.39 & 11.3 & -1.3 & 9.8 \\
\hline
\end{tabular}

Labour, Employment and Work in New Zealand 1996 
Table 2. Summary measures of earnings dispersion

\begin{tabular}{|c|c|c|c|c|c|c|c|}
\hline Measure & 1984 & 1986 & 1988 & 1990 & 1992 & 1994 & 1995 \\
\hline \multicolumn{8}{|c|}{ Weekly earnings, all employees } \\
\hline $\mathrm{CV}$ & 58.9 & 58.4 & 60.7 & 64.9 & 65.3 & 72 & 69.3 \\
\hline SDLOG & 0.82 & 0.79 & 0.81 & 0.79 & 0.83 & 0.87 & 0.81 \\
\hline $90 / 50$ & 1.83 & 1.79 & 1.82 & 1.89 & 1.89 & 1.85 & 1.83 \\
\hline $10-50$ & 0.3 & 0.31 & 0.3 & 0.31 & 0.28 & 0.27 & 0.28 \\
\hline $90 / 10$ & 6.15 & 5.8 & 6.04 & 6.18 & 6.82 & 6.97 & 6.62 \\
\hline
\end{tabular}

Weekly earnings, full-time employees

$\begin{array}{lccccccc}\text { CV } & 45.3 & 45.9 & 48.1 & 52.8 & 51.7 & 58.2 & 56.9 \\ \text { SDLOG } & 0.43 & 0.44 & 0.45 & 0.48 & 0.5 & 0.5 & 0.5 \\ 90 / 50 & 1.7 & 1.67 & 1.68 & 1.74 & 1.74 & 1.76 & 1.74 \\ 10-50 & 0.59 & 0.59 & 0.57 & 0.57 & 0.57 & 0.58 & 0.57 \\ 90 / 10 & 2.89 & 2.83 & 2.93 & 3.05 & 3.08 & 3.04 & 3.04\end{array}$

Hourly earnings, all employees

$\begin{array}{lccccccc}\text { CV } & 47.4 & 47.1 & 46.9 & 54.8 & 50 & 55.7 & 55.7 \\ \text { SDLOG } & 0.46 & 0.46 & 0.46 & 0.49 & 0.49 & 0.5 & 0.49 \\ 90 / 50 & 1.74 & 1.71 & 1.74 & 1.77 & 1.75 & 1.72 & 1.75 \\ 10-50 & 0.6 & 0.6 & 0.6 & 0.59 & 0.59 & 0.59 & 0.6 \\ 90 / 10 & 2.92 & 2.86 & 2.91 & 3 & 2.95 & 2.91 & 2.9\end{array}$

Hourly earnings, males

$\begin{array}{lccccccc}\text { CV } & 46.7 & 45.6 & 46.2 & 53.5 & 50.1 & 59.6 & 56.6 \\ \text { SDLOG } & 0.46 & 0.47 & 0.47 & 0.5 & 0.5 & 0.54 & 0.52 \\ 90 / 50 & 1.71 & 1.64 & 1.68 & 1.77 & 1.8 & 1.79 & 1.79 \\ 10-50 & 0.59 & 0.59 & 0.58 & 0.56 & 0.57 & 0.56 & 0.55 \\ 90 / 10 & 2.91 & 2.79 & 2.91 & 3.18 & 3.16 & 3.21 & 3.23\end{array}$

Hourly earnings, females

$\begin{array}{lccccccc}\text { CV } & 43.2 & 44.7 & 43.4 & 53.8 & 48.4 & 46.2 & 52.9 \\ \text { SDLOG } & 0.42 & 0.4 & 0.42 & 0.46 & 0.47 & 0.43 & 0.44 \\ 90 / 50 & 1.66 & 1.62 & 1.61 & 1.65 & 1.66 & 1.63 & 1.67 \\ 10-50 & 0.64 & 0.64 & 0.62 & 0.61 & 0.62 & 0.62 & 0.66 \\ 90 / 10 & 2.61 & 2.53 & 2.59 & 2.71 & 2.7 & 2.64 & 2.54\end{array}$

$\mathrm{CV}=$ coefficient of variation. SDLOG $=$ the standard deviation of log earnings.

$90 / 50=$ the 90 th percentile/the median. The other percentile ratios are similarly defined.

end of the period than at the beginning, the percentile-based measures of dispersion were essentially unchanged.

The shape of the hourly earnings distribution is illustrated in Figure 2, showing the positions of selected percentiles in relation to the median in each year. This information confirms the basic message that there was little change in the dispersion of hourly earnings over the decade-most declines remained in a roughly constant position. The 95 th percentile does show some upward movement, increasing from around 205 percent of the median in the 1980 s to around 215 percent in 1995. Further analysis of the data showed that increases in the relative earnings of a small group of earners at the very top of the distribution, above the ninetieth percentile, were largely responsible for the rise in the non-percentile meas- ures of dispersion (the coefficient of variation and the standard deviation of $\log$ wages). 6

The rise in weekly earnings inequality at a time of little change in the dispersion of hourly earnings was caused by growing variation in the usual weekly hours reported by respondents. In particular, there was an increase in the proportion of wage and salary earners reporting usual weekly hours of 45 or more, raising the upper deciles of the hoursof-work distribution.

A more complex picture of the wage structure emerges if male and female employees are considered separately. There are signs of increasing inequality in male hourly earnings from 1988 onwards. The percentile ratios indicate that this 
Figure 2. Percentiles of the hourly earnings distribution

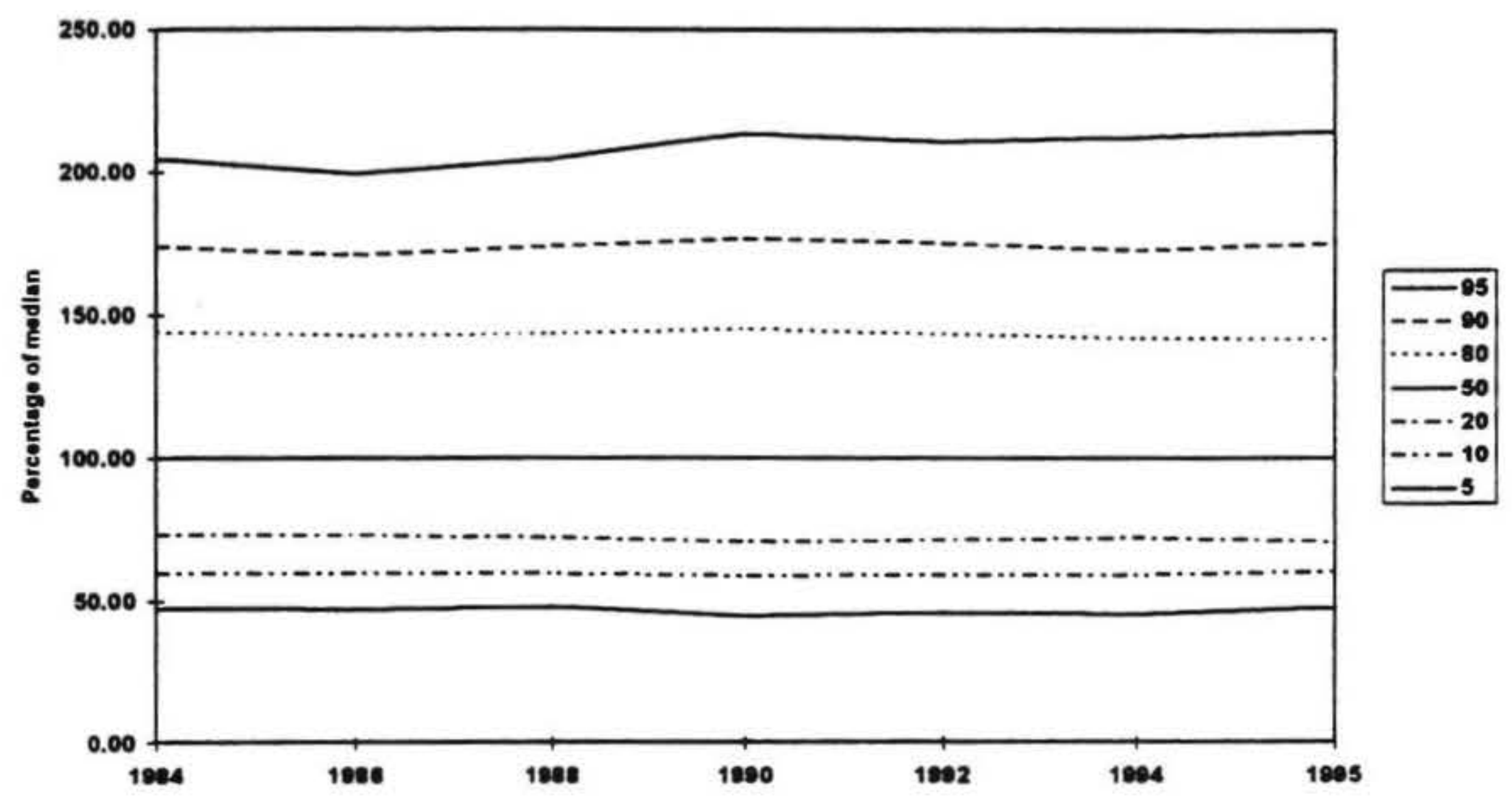

was mainly due to increases in relative earnings at the top of the distribution, although there is also some evidence of a downward shift of the lowest percentiles. While the female earnings data indicate an increase in dispersion between 1988 and 1990, that change was not sustained, and in 1995 the spread of female hourly earnings was similar to that observed in the mid 1980s.

Figure 3, showing the total percentage changes over the decade in the log real hourly earnings of males and females at different positions in the distribution of earnings, confirms this picture of rising male and constant female inequality. Movements in male earnings were positively correlated with level of earnings, causing the line on the graph for males to be positively sloped. The largest increases were experienced by males at the upper quartile of the distribution. The slope of line for females is approximately flat, indicating that earnings increases for females were not strongly correlated with position in the distribution.

\section{Decomposition of changes in the hourly earn- ings distribution}

The fact that the aggregate hourly earnings distribution did not widen materially between 1984 and 1995 is somewhat surprising, given the substantial economic and regulatory reforms implemented in New Zealand over the period. In fact, the earnings distribution was not rigid: rather, there were a number of changes in the structure of earnings within and across labour force groups, which appear to have offset each other.

Figure 3. Change in log real hourly earnings by decile, 1984-95

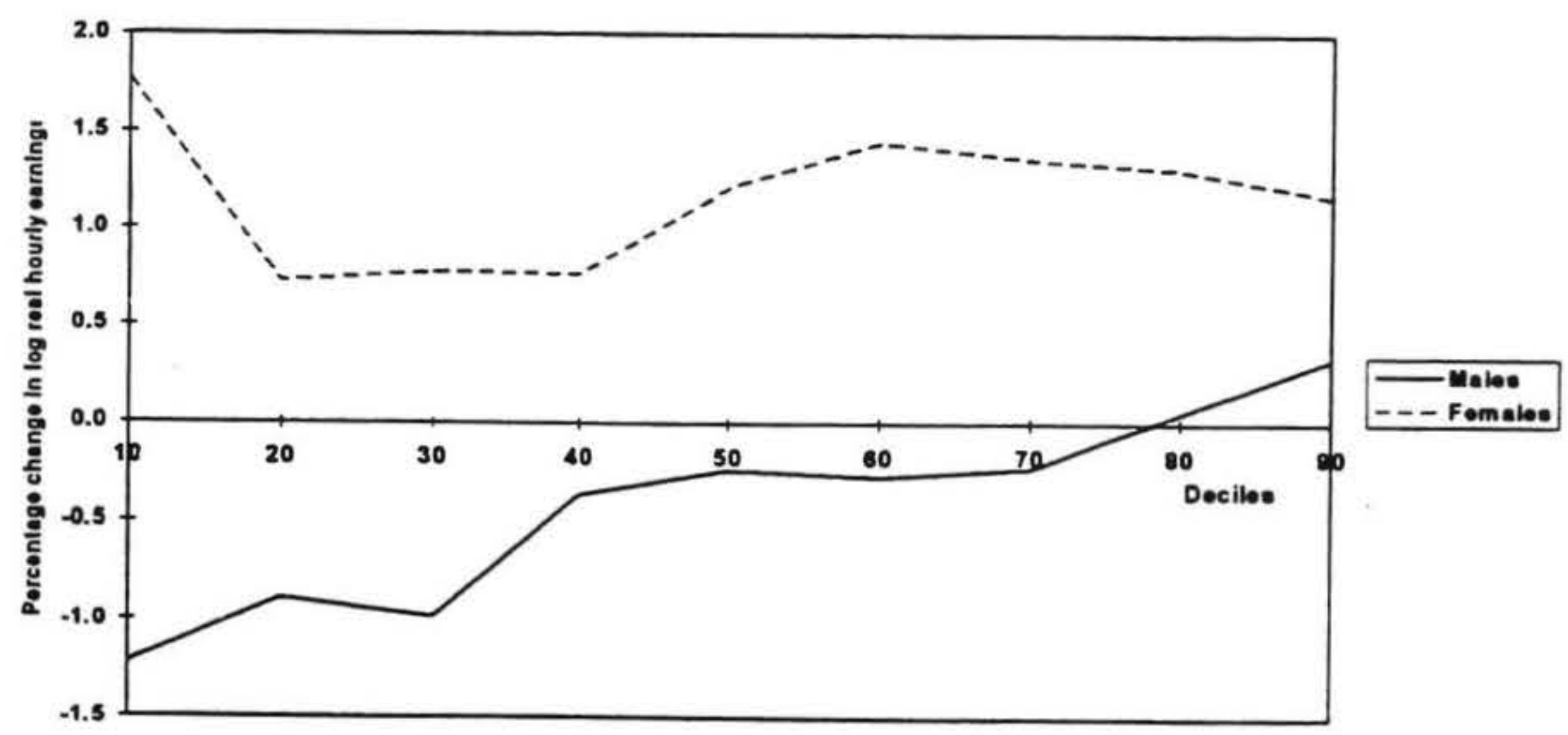


Changes in individual earnings dispersion may occur as a result of shifts in the composition of employment between groups with different observable skill characteristics (such as education and experience), changes in the returns to these observable skill characteristics, or changes in the distribution and returns to unobserved characteristics. Information on the main changes in the employment shares and real hourly earnings of different labour force groups is presented in Table 3. Table 4 provides information on changes in the relative earnings of each group.

Between 1984 and 1995, there was a 4.4 percent increase in the female share of wage and salaried employment (as measured by the HES). Prime-aged workers, non-Päkehä, and workers with school or post-school qualifications also increased their relative shares. The employment shares of males, young people, Päkehä and workers without any formal qualifications declined.

The most striking change in the structure of earnings over the decade was the convergence of male and female average hourly earnings. The real hourly earnings of male employees fell slightly, while those of females increased by around ten percent, leading to a substantial reduction in the size of the gender earnings differential. The ratio of female to male median hourly earnings rose from 0.79 in 1984 to 0.88 in 1995.

The data in Tables 3 and 4 also point to reductions in the relative earnings of young workers and workers without formal qualifications. They indicate a rise in the relative earnings of employees with post-school qualifications between 1984 and 1990, which was reversed between 1990 and 1995. However, the differences in wage movements across

Table 3: Changes in employment shares and relative earnings 1984-95

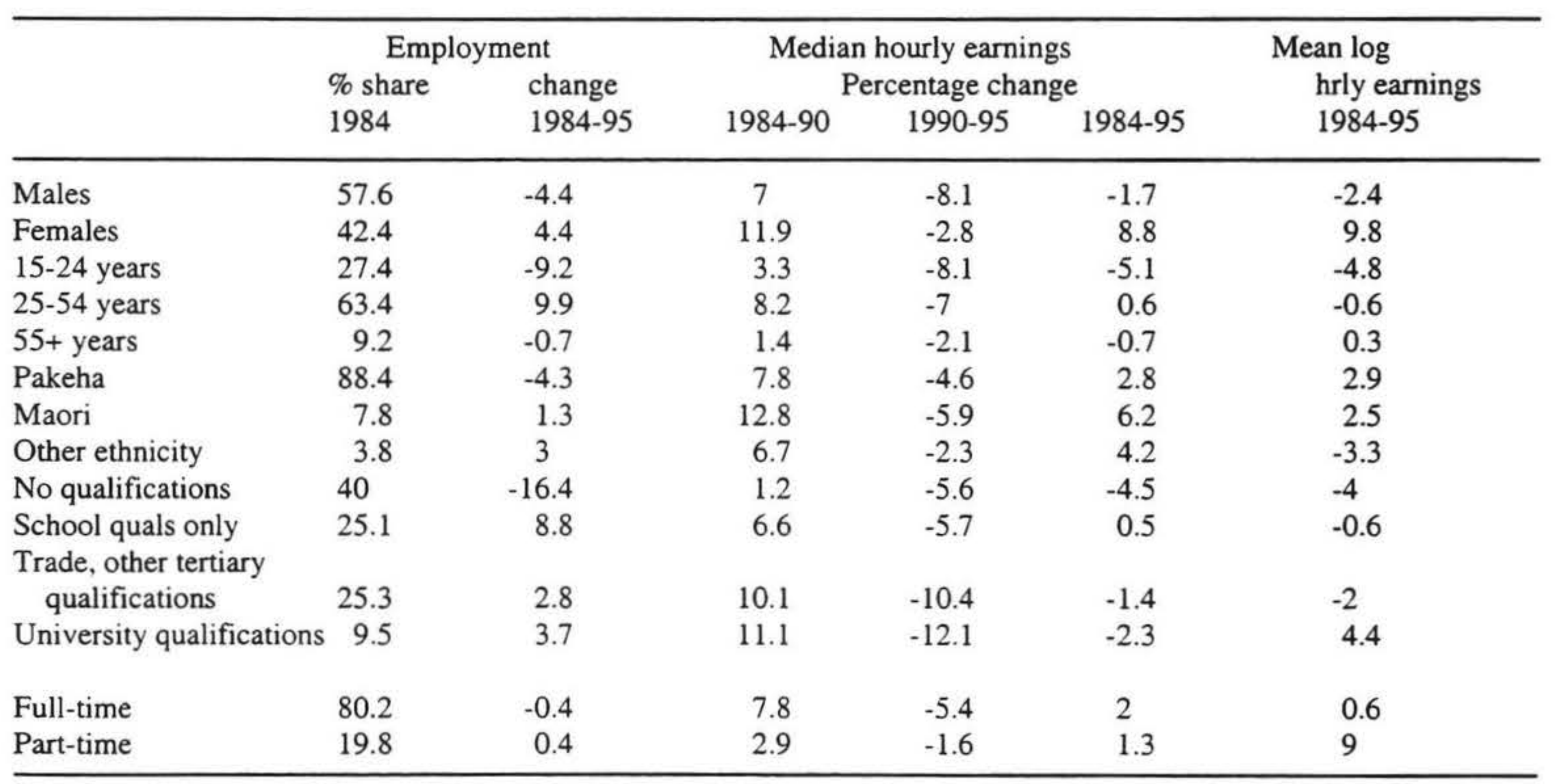

Table 4: Relative earnings of demographic and skill groups

\begin{tabular}{|c|c|c|c|c|}
\hline & \multicolumn{4}{|c|}{$\begin{array}{l}\text { Ratio of group's median hourly earnings to median hourly } \\
\text { earnings all employees }\end{array}$} \\
\hline & 1984 & 1990 & 1995 & $1984-95$ \\
\hline Males & 1.1 & 1.1 & 1.06 & -0.05 \\
\hline Females & 0.87 & 0.91 & 0.93 & 0.05 \\
\hline $15-24$ years & 0.79 & 0.76 & 0.73 & -0.06 \\
\hline $25-54$ years & 1.09 & 1.09 & 1.07 & -0.02 \\
\hline $55+$ years & 1.05 & 0.99 & 1.02 & -0.04 \\
\hline Pakeha & 1.01 & 1.01 & 1.01 & 0 \\
\hline Maori & 0.89 & 0.93 & 0.92 & 0.03 \\
\hline Other ethnicity & 0.93 & 0.92 & 0.94 & 0.01 \\
\hline No qualifications & 0.89 & 0.83 & 0.82 & -0.06 \\
\hline School qualifications only & 0.96 & 0.95 & 0.94 & -0.02 \\
\hline Trade, other tertiary qualifications & 1.14 & 1.16 & 1.09 & -0.05 \\
\hline University qualifications & 1.47 & 1.52 & 1.4 & -0.07 \\
\hline Full-time & 1.05 & 1.05 & 1.04 & -0.01 \\
\hline Part-time & 0.82 & 0.78 & 0.81 & -0.01 \\
\hline
\end{tabular}


these broad age, ethnic and qualifications groups are not large. In addition, there is considerable year to year volatility in the estimates of subgroup earnings and earnings ratios, reflecting sampling and other measurement errors. ${ }^{7}$

Interpretation of these data on subgroup earnings and earnings ratios is complicated by the fact that the demographic and skill profiles of each group could be changing over time, affecting earnings in ways that cannot be captured by disaggregations along a single dimension. To explore the changes in the independent influence of each measured attribute on earnings, a simple linear earnings equation was estimated for each annual dataset. The basic form of the earnings equation used for this purpose was as follows:

ln $Y_{i}=a+b_{1}$ Female $+b_{2}$ Age $+b_{3}$ Age $^{2}+b_{4}$ No qualifications $+b_{5}$ Tertiary qualifications + $b_{6}$ University qualifications $+b_{7}$ Mäori $+b_{8}$ Other ethnicity $+b_{9}$ Part-time $+b_{10}$ Qualifications not specified $+b_{11}$ Ethnicity not specified $+u_{i}$

where the dependent variable is the log of real total hourly earnings; 'Tertiary qualifications' represents trade certificates, teaching and nursing diplomas and other non-university post-school qualifications; and the 'Other ethnicity' group includes Pacific Islanders and people of non-European racial descent. Age and age squared are measured in years, while all other independent variables are represented by dummies. The nine binary variables in the basic model estimate variations in average earnings in comparison to the excluded group of male, full-time, Päkehä earners with school qualifications. ${ }^{8}$ The results are summarised in Table 5 .

The coefficients for 'Female' can be interpreted as measuring that part of the gender earnings gap that cannot be attributed to gender differences in age, qualifications, ethnicity and full-time or part-time status. These coefficients are consistently negative, but they decline in size over the period. In 1984 , the predicted earnings of females were 16.2 log points, or about 17.6 percent, lower than the predicted earnings of males after differences in the other observed characteristics are controlled for. In 1995, the predicted earnings of females were $9.2 \mathrm{log}$ points or about 9.6 percent below those of males, after controlling for the other variables. These results suggest that the decline in the 'gross' gender earnings gap was not simply the result of the changes in the age, educational, ethnic and part-time/full-time profiles of males and females, as measured in this model. Changes in other productive characteristics not included in the model, or changes in the relative 'prices' paid for male and female workers with similar productive characteristics, are likely to

Table 5. Regression of individual characteristics on log hourly earnings

\begin{tabular}{|c|c|c|c|c|c|c|c|}
\hline & 1984 & 1986 & 1988 & 1990 & 1992 & 1994 & 1995 \\
\hline \multicolumn{8}{|l|}{ Coefficients } \\
\hline Intercept & 6.076 & 6.003 & 6.067 & 5.906 & 5.819 & 5.972 & 5.855 \\
\hline Female & -0.162 & -0.169 & -0.15 & -0.146 & -0.115 & -0.079 & -0.092 \\
\hline Age & 0.062 & 0.064 & 0.057 & 0.067 & 0.069 & 0.057 & 0.062 \\
\hline Age2 & $-6.92 E-04$ & $-7.22 \mathrm{E}-04$ & $-6.16 E-04$ & -7.51E-04 & $-7.87 \mathrm{E}-04$ & $-6.17 \mathrm{E}-04$ & $4-6.73 \mathrm{E}-04$ \\
\hline No qualification & -0.154 & -0.148 & -0.147 & -0.181 & -0.153 & -0.161 & -0.217 \\
\hline \multicolumn{8}{|l|}{ Trade, other tertiary } \\
\hline qualifications & $0.056^{*}$ & 0.098 & 0.118 & 0.114 & $0.067^{*}$ & $0.059^{*}$ & 0.062 \\
\hline University qualifications & 0.257 & 0.337 & 0.336 & 0.344 & 0.31 & 0.269 & 0.345 \\
\hline Maori & $-0.032 *$ & $0.012 *$ & $-0.031^{*}$ & $-0.018^{*}$ & $-0.023^{*}$ & $-0.078^{*}$ & $-0.0004 *$ \\
\hline Other ethnicity & $-0.022 *$ & $-0.091^{*}$ & $-0.075^{*}$ & $-0.061^{*}$ & $-0.060^{*}$ & -0.137 & -0.107 \\
\hline Part-time worker & -0.117 & -0.116 & -0.121 & -0.095 & $-0.073^{*}$ & -0.127 & $-0.030 *$ \\
\hline \multicolumn{8}{|l|}{ Standard errors } \\
\hline Intercept & 0.0468 & 0.0489 & 0.0452 & 0.0613 & 0.0695 & 0.0715 & 0.0738 \\
\hline Female & 0.0133 & 0.0133 & 0.0119 & 0.0151 & 0.0173 & 0.0169 & 0.0163 \\
\hline Age & 0.0027 & 0.0028 & 0.0026 & 0.0035 & 0.0039 & 0.004 & 0.0041 \\
\hline $\mathrm{Age}^{2}$ & $3.42 E-05$ & $3.66 E-05$ & $53.38 E-05$ & $4.61 E-05$ & $5.03 E-05$ & $5.17 E-05$ & $5 \quad 5.23 E-05$ \\
\hline No qualification & 0.016 & 0.0155 & 0.0143 & 0.0187 & 0.0229 & 0.0227 & 0.0214 \\
\hline \multicolumn{8}{|l|}{ Trade, other tertiary } \\
\hline qualifications & 0.0175 & 0.0173 & 0.0149 & 0.0184 & 0.0216 & 0.0214 & 0.0203 \\
\hline University qualifications & 0.0233 & 0.025 & 0.0209 & 0.0254 & 0.0274 & 0.0264 & 0.0257 \\
\hline Maori & 0.0231 & 0.0246 & 0.0221 & 0.0269 & 0.0321 & 0.0292 & 0.0274 \\
\hline Other ethnicity & 0.0315 & 0.0271 & 0.0222 & 0.0282 & 0.0305 & 0.0313 & 0.031 \\
\hline Part-time worker & 0.0166 & 0.017 & 0.0153 & 0.0189 & 0.0211 & 0.0204 & 0.0206 \\
\hline$F$ & 182 & 189 & 208.5 & 134.8 & 83.9 & 90.5 & 104.2 \\
\hline Adj R2 & 0.313 & 0.33 & 0.335 & 0.304 & 0.25 & 0.228 & 0.26 \\
\hline Sample size & $3981 \quad 38$ & $818 \quad 47$ & 745 & $372 \quad 27$ & 34 & 0342 & 947 \\
\hline \multicolumn{8}{|c|}{$*$ denotes NOT statistically significant at the $95 \%$ significance level } \\
\hline
\end{tabular}


have played some role.

None of the other coefficients shows substantial or consistent shifts over the decade. There is some evidence of a small rise in the earnings premium for age and/or experience, leading to a rise in the estimated age at which earnings peak, and an associated increase in the earnings of employees in their late 40 s and 50 s relative to the younger age groups. The coefficients for qualifications indicate that educational attainment accounts for a substantial part of the 'explained' variation in earnings, but it is not clear that the size of this contribution has either risen or fallen over time. There is volatility from year to year but not a clear trend. In most years, the coefficients for Mäori and the 'other' ethnic group (mainly Pacific Island peoples) are small and not statistically significant, suggesting that the independent effects of ethnicity on earnings are relatively weak. The coefficients for part-time status are also small and not significant in all years.

It is worth noting that the fit of this simple model of individual earnings, as indicated by the $\mathrm{R}^{2}$ and $\mathrm{F}$ values, was lower at the end of the period than in the 1980s. The portion of total earnings variation that can be 'explained' in terms of the variables included in this simple human capital model has been declining over time, suggesting that the role of other, unmeasured variables is becoming more important.

The impact of changes in the composition of wage and salaried employment and changes in the relative earnings of different labour force groups on the total earnings distribution can be analysed using the decomposition property of variances. ${ }^{9}$ In any given year, the variance of log hourly earnings can be decomposed into the following components:

$$
\sigma_{\mathrm{t}}^{2}=\hat{\mathrm{A}} \mathrm{s}_{\mathrm{it}} \cdot \sigma_{\mathrm{it}}^{2}+\hat{\mathrm{A}} \mathrm{s}_{\mathrm{it}} \cdot\left[\mathrm{w}_{\mathrm{it}}-\mathrm{w}_{\mathrm{t}}\right]^{2}
$$

where $\sigma_{t_{2}}^{2}$ is the variance of log real hourly earnings in year $t, s_{i t}, \sigma_{i t}, w_{i t}$ are respectively the share of employees, the variance of log hourly earnings and average log real hourly earnings for group $i$ in year $t$, and $\boldsymbol{w}_{t}$ is average log real hourly earnings in year $t$. In this model, $\sigma_{i t}$ represents within-group inequality and $\left[w_{i t}-w_{t}\right]^{2}$ represents betweengroup inequality. By examining the effects of shifts in $s i t$ across time it is possible to establish the effect of changes in the composition of employment on the variance of log earnings; similarly, by allowing $\sigma_{i t}$ and $\left[w_{i t}-w_{t}\right]^{2}$ to vary, the role of changes in within-group and between-group earnings inequality in explaining changes in the total inequality of earnings can be ascertained (Borland and Wilkins, 1996, p.18). Although the net change in the total variance of log real hourly earnings between 1984 and 1995 was small and not statistically significant, a decomposition can help to reveal any underlying tendencies towards greater or reduced inequality.

Table 6 presents the results of the decomposition of the total change in log hourly earnings by gender, age group, and qualifications. The age groups used for this purpose were 1524 years; $25-39$ years; and 40 year or over. For the qualifications decomposition, earners were classified by their highest qualification into the following groups: no formal qualifications; school qualifications only; university qualifications; and other, non-university qualifications including teaching diplomas and trade certificates.

The first two columns of the table, giving the results of the gender decomposition, indicate that the main effect on the total distribution came from an increase in the within-group variance term. This was caused by a sizeable rise in the within-group variance of male earnings and a very small rise in the variance of female earnings. The reduction in the between-gender variance of earnings partially offset this effect. An increase in the female share of employment also had a small negative effect on total earnings inequality. If the gap between average male and average female earnings, or the female share of waged and salaried employment had remained unchanged, total earnings inequality in 1995 is likely to have been higher than the level actually observed.

The remaining columns of Table 6 summarise the decomposition of employment by age group and level of qualifications. In both cases, changes in within-group inequality accounted for most of the movements towards higher inequality. Shifts in the composition of employment across groups, and shifts in the variance of earnings across groups, also had effects operating in the direction of higher inequality, but these effects were much smaller.

\section{Table 6: Decomposition of inequality in hourly earnings: $1984-1995$}

\section{Change in variance of log hourly earnings 1984-95}

Decomposition by:

Gender Age group

Qualifications
1. Change in within-group inequality

a. Due to change in variance within groups

b. Due to change in share of each group

c. Interaction

2. Change in between-group inequality

a. Due to change in variance btwn groups

b. Due to change in share of each group

c. Interaction

0.0378

0.041

$-0.0018$

$-0.0014$

$-0.0095$

-0.0095
0.0003
-0.0003

0.0173

0.0079

0.0088
0.0023
-0.0032

0.0295

0.0267

0.0013

0.0015

3. Total change

0.0283

0.0283

$-0.0011$

0.0086

$-0.0055$

$-0.0043$ 
Further analysis of changes in within-group earnings inequality indicated that workers in the 40 plus age group accounted for the largest portion of the rise in inequality. The rise in inequality was also concentrated among workers with post-school qualifications - there is little evidence of growth in dispersion among the less qualified groups. Percentile measures of the earnings of workers with post-school qualifications indicate some decline in relative earnings at bottom end of the distribution, as well as a rise in the relative earnings of those at the upper end. Males with university qualifications (as opposed to females or workers with trade, technical or other tertiary qualifications) were responsible for most of the rise in dispersion. The growth in earnings inequality also appears to have come from industries in which private sector employment predominates, rather than industries with high levels of public sector employment.

\section{Summary and discussion}

The main changes in the hourly earnings structure between 1984 and 1995 can be summarised as follows. First, a small rise in average real hourly earnings during the 1980s was partially offset by a decline in the early 1990 s, leading to a very modest improvement in the real value of average hourly earnings over the decade as a whole. Second, the overall increase in inequality was very small, and caused by a rise in the relative earnings of workers at the top of the distribution, rather than a decline in the relative earnings of low wage workers. Third, less-skilled and less-educated workers did not experience substantial reductions in their relative earnings, as was the case in the United States and the United Kingdom. This is clear from the shape of the aggregate earnings distribution, and is confirmed by the evidence on the trends in earnings differentials by level of educational attainment. Although there were signs of a rise in qualifications-based earnings differentials during the late 1980s, developments in the 1990s did not reinforce that trend and in the mid 1990s, qualifications-based earnings differentials (after controlling for differences in age and gender) were no larger than in 1990. Fourth, there was a substantial reduction in gender differentials over the decade, reflecting an upward shift of all levels of the female distribution and some downward movement of the male distribution. Fifth, there was an increase in earnings inequality among males with postschool qualifications. The impact of this trend on the total earnings distribution was offset by other factors, including the convergence of the male and female earnings distributions.

One possible explanation for the absence of more change in earnings inequality is that the supply of differently-skilled labour adjusted in response to shifts in demand, weakening the pressures for skill-based wage differentials to widen. There is some evidence of a demand shift towards more highly skilled workers in the 1980s - the direction of the changes in employment shares and relative wages by level of qualifications in the years to 1990 is consistent with a skillbiased demand shift. In the first half of the 1990s, however, wage movements were not correlated with educational level, and there was strong growth in the employment of less skilled as well as more highly skilled workers. Due to the rapid growth in tertiary education participation rates in the 1980 s, the tertiary-educated share of the labour force rose rapidly from about 1988 onwards, and it is possible that by the early 1990 s the growth of supply outstripped the growth of demand, putting downward pressure on the earnings of graduates. At the other end of the wage spectrum, the labour force share of workers without any formal qualifications contracted by around one-third over the decade, reflecting both changes in educational patterns and a decline in the labour force participation rates of men and women in this group. It is possible that an inward shift in the supply of less educated workers helped to prevent a decline in the relative wages of this group in the first half of the 1990s.

Another hypothesis is that there were changes in the relative 'quality' of workers with different levels of educational attainment (i.e., their average productive characteristics) which countered any tendencies towards higher educational wage differentials. Arguably, the rapid expansion of tertiary education in the 1980 s may have reduced the average quality of graduates, leading to lower entry-level wages. Both the role of demand and supply shifts, and the role of changes in the average skills and attributes of differently qualified groups in the labour force, require further investigation before it can be concluded that these forces did in fact operate to counteract growth in wage dispersion.

A convergence of the average skill-related characteristics of male and female employees is likely to be the single most important cause of the decline in the male-female earnings gap. In 1984, female wage and salary earners were more likely than males to have no formal qualifications, and less likely to have a post-school qualification. By 1995 the male and female qualifications profiles were much closer to one another: similar proportions of male and female earners were without formal qualifications, and the gap in postschool attainments was much reduced. There was also some convergence over the decade in the mean ages of male and female employees and their full-time/part-time mix.

Given this convergence in observed skill characteristics, it would have been surprising if gender wage differentials had not closed at all. A Blinder-type decomposition of the components of the male/female wage gap, using the information available from the HES datasets on skill-related characteristics (age, qualifications, ethnicity and part-time status) and the earnings premia associated with those characteristics, indicates that about half the total reduction in the gender log hourly earnings differential between 1984 and 1995 can be attributed to the increased similarity of male and female characteristics. ${ }^{10}$ However, this is likely to be an underestimation of the true contribution of changes in male and female productive characteristics, because it does not take into account a range of other relevant variables not measured in the HES datasets, such as years of work experience and employment-related training. ${ }^{11}$ The remaining part of the reduction in the gender pay gap, representing changes in the relative 'prices' paid for male and female labour of a given quality, could potentially be the result of changes in variables that lie outside the model of individual earnings, such as job or firm characteristics, or shifts in the 
demand for female labour relative to the demand for male labour. Again, further analysis is required to identify and disentangle these causes.

Changes in wage setting institutions and practices do not seem to have had a measurable impact on the distribution of earnings in the early 1990s. This is surprising, given the extent of the fall in union membership and the shift from centralised to decentralised, firm-based wage setting - changes that might have been expected to lead to greater variation in wage adjustments and, in time, greater dispersion in the wage structure. The reasons why there is so little evidence of widening wage differentials in the post-ECA era deserve further investigation and debate.

\section{Conclusions}

This paper has examined the distribution of pre-tax earnings from waged and salaried employment over the 1984 to 1995 period, using estimates of individuals' weekly and hourly earnings from the Household Economic Survey. When adjusted for inflation by the CPI excluding the effects of GST, these data show a small rise in average real hourly earnings during the 1980 s, which was partially offset by a small decline in the real value of hourly earnings in the early 1990s.

The distribution of weekly earnings widened over the decade, due to growing variation in usual weekly hours worked. In contrast, there was surprisingly little change in the overall dispersion of hourly earnings. A small increase in inequality was recorded, caused by a rise in the relative earnings of workers at the very top of the distribution, above the ninetieth percentile. Further analysis of the data indicated that a tendency towards higher earnings inequality among males with post-school qualifications was mainly responsible for the upward movement of the upper tail of the earnings distribution. The male hourly earnings distribution became less equal over the decade, but the effects of this change on the total earnings structure were offset by a rise in the female share of employment and a narrowing of the gap between male and female average earnings.

There was a substantial reduction in the gender earnings gap between 1984 and 1995, reflecting an upward shift of all levels of the female earnings distribution and some downward movement of the male distribution. By 1995, the crude gender differential in average hourly earnings was about one-half of its size in 1984. A crude decomposition of the sources of change indicated that at least half of the reduction in the gender earnings gap was due to convergence in the productivity-related characteristics of male and female employees, as proxied by measured variables such as educational level and age.

There were signs of a rise in qualifications-based earnings differentials during the late 1980s, but developments in the 1990 s did not reinforce that trend and in the mid 1990s, qualifications-based earnings differentials were not significantly larger than in 1990.

\section{Further research}

Further assessment of the effects of supply and demand shifts on the earnings differentials for workers grouped by level of educational attainment could be undertaken, using the formal tests of supply and demand shifts devised by Katz and Murphy (1992). Improved estimates of the contribution to earnings of various individual attributes, using data on attributes not measured in HES and more advanced estimation methods, would be useful. It may also be worth comparing the trends in wage levels and wage dispersion across industries in attempt to identify any significant differences in outcomes which may be associated with differences in the impact of policy reforms.

\section{Notes}

1. The Household Economic Survey (HES) and the Quarterly Employment Survey (QES) are the two official surveys which measure earnings in nominal dollars on a regular basis. For a number of reasons, QES measures of average total hourly earnings have been around 5-10 percent higher than the HES measures over the last ten years. The price indices available for converting measures of nominal earnings to constant dollars include: the Producers Price Index; the official CPI; the CPI excluding credit costs; and the CPI adjusted for the impact of the changes in indirect tax regimes (such as the introduction of GST) on prices. The CPI is generally considered to be conceptually more appropriate than the PPI if the focus of interest is on the real value of gross earnings to workers, rather than the labour costs of employers.

2. The official CPI, incorporating the effect of GST on prices, is the most appropriate measure to use when deflating after-tax earnings.

3. The GST-adjusted CPI series calculated by the RBNZ was used for this purpose. Roger (1995) outlines the methods used to calculate this series.

4. The possible reasons for the difference between the trends shown by the two series include: (a) actual hours worked and reported by HES respondents may have risen relative to hours paid for and reported by QES respondents during the early 1990s, increasing the gap between the two measures of average hourly earnings; and (b) earnings in informal and household sector jobs, which are covered by the HES but not the QES, may have fallen in relative terms during the early 1990s.

5. In Dixon (1996) gross earnings data from the HES were inflation adjusted using the official CPI. The earnings data given in that paper relating to the years 1984, 1986 and 1988 can be scaled to match those presented here by multiplying each number by a constant, representing the ratio of the two price indices. The changes in the method of price adjustment does not affect the analysis of earnings within specific years.

6. If the top five percent of cases in each year are excluded, these measures show much less upward movement. One 
reason for giving greater weight to measures of dispersion that are not influenced by observations at the extremes of the distribution is that these outlying observations are more likely to contain measurement error.

7. This volatility is not uncommon in earnings data. For example, Bar-Or et al (1995), investigating the wage premium to a university education in Canada, found considerable noise from year to year in measures of the university wage premium, even when quantiles such as medians were used as measures of the centre of the distribution and thousands of observations were available.

8. Gender, age, ethnicity and qualifications are standard human capital variables. The variables age and age squared were included to control for the non-linear effect of work experience, which is expected to increase with age. A dummy for part-time status was included to capture any differences between the earnings functions of part-time and full-time employees, arising from differences in unmeasured dimensions of productivity (such as firm-specific training) or from differences in the way in which measured attributes such as age and qualifications are rewarded.

9. Borland and Wilkins (1996) and Karoly (1992) use this method to analyse shifts in the earnings distributions of Australia and the United States.

10. Paci and Joshi (1996, pp.15-16) describe this method of decomposing the components of the gender wage gap.

11. Overseas studies suggest that increases in the average work experience of females have helped to reduce gender pay differentials. See, for example, Paci and Joshi, 1996.

\section{References}

Bar-Or, Y. Burbridge, J, Magee, L. and Robb, L 1995 The wage premium to a university education in Canada, 1971-1991 Journal of Labour Economics Vol 13 (4): 762-94

Blackburn, M. and Neumark, D. 1993 Omitted-ability bias and the increase in the return to schooling. Journal of Labour Economics 11(1): 521-44

Borland, J. and Wilkins, R. 1996 Earnings inequality in Australia The Economic Record 72(1) : 7-23

Dixon, S. 1996 The distribution of earnings in New Zealand 1984-94. Labour Market Bulletin 1996(1): 45 100

Freeman, R 1993 How much has de-unionisation contributed to the rise in male earnings inequality? Uneven Tides: Rising Inequality in America (Ed.) Sheldon Danziger and Peter Gottschalk, New York, Russell Sage: 99-133

Gregg, P. and Machin S. 1994 Is the UK rise in inequality different? In The UK labour market: Compara- tive aspects and institutional developments (Ed.) Ray Barrell, Cambridge University Press: 93125

Gunderson, M. 1989 Male-female wage differentials and policy responses. Journal of Economic Literature, 28(1): 46-72

Karoly, L. 1992 Changes in the distribution of individual earnings in the United States: 1967-1986. Review of Economics and Statistics, 74(1): 107-115

Katz, L and Murphy, K 1992 Changes in relative wages, 1963-87: Supply and demand factors. Quarterly Journal of Economics 107(1): 35-78

Katz, L., Loveman, G. and Blanchflower, D. 1993 A comparison of changes in the structure of wages in four OECD countries. National Bureau of Economic Research Working Paper Series, No. 4297.

Levy, F. and Murnane, R. 1992 US earnings levels and earnings inequality: a review of recent trends and proposed explanations. Journal of Economic Literature, 30(3): 1333-81

Maré, D. 1997 Labour market trends, cycles and outlook. In Morrison, P.S. (ed) Labour, employment and work in New Zealand. Proceedings of the Seventh Conference, Victoria University of Wellington.

Mowbray, M. 1993 Incomes Monitoring Report, 1981-91. Social Policy Agency, Wellington.

Mowbray, M. and Dayal, N 1994 The fall and rise (??) of household incomes. Social Policy Journal of New Zealand. 2:114-22.

Murphy, K. and Welch, N. 1991 The role of international trade in wage differentials, in Workers and their wage: Changing patterns in the US. (Ed.) Marvin Kosters, Washington DC, AEI Press: 39-69

Murphy, K. and Welch, F. 1992 The structure of wages. Quarterly Journal of Economics, 107(1): 285326.

New Zealand Planning Council 1988 For richer for poorer: Income and wealth in New Zealand. Wellington, NZPC.

New Zealand Planning Council 1990 Who gets what? The distribution of income and wealth in New Zealand. Wellington, NZPC.

Nickell, S. and Bell, B. 1996 Changes in the distribution of wages and unemployment in OECD countries. American Economic Review, 86(2): 302-3083 
OECD (1993) Earnings inequality: changes in the 1980s. OECD Employment Outlook, July 1993: 157-84.

OECD (1996) Earnings inequality, low-paid employment and earnings mobility. OECD Employment Outlook, July 1996: 59-108.

Paci, P. and Joshi, H. 1996 Wage differentials between men and women: Evidence from cohort studies. Department for Education and Employment Research Series No. 71, London.

Roger, S. 1995 The GST shocks: revisited and revised. Reserve Bank research memorandum \#M95/45.

\section{Author}

Sylvia Dixon is a Senior Economic Analyst in the Labour Market Policy Group of the Department of Labour. 